\title{
China's Monetary Ambitions: RMB Internationalization in Comparative Perspective
}

\author{
Injoo Sohn
}

\begin{abstract}
What is the political process of China's move to internationalize its home currency? How different is Chinese RMB internationalization from the currency internationalization of other great powers? What is the international destiny of the RMB? By addressing such questions, this study challenges three prevailing views of RMB internationalization: realist determinism, American exceptionalism, and liberal hype. This article argues that a feedback model can be useful for our understanding of the process - timing and direction - of RMB internationalization. This study also identifies key similarities and differences among Germany of the 1930s, the United States of the 1960s, and today's China in their currency internationalization. This comparison will reveal important structural factors that may contribute to a slow path to full RMB internationalization, and the emergence of the hybrid model of Chinacentered monetary order in the East Asian region.
\end{abstract}

Key Words: RMB, currency internationalization, monetary diplomacy, international order, feedback

$\mathrm{T}$ his study seeks to address the process, nature, and prospect of renminbi (or RMB) internationalization. ${ }^{1}$ What is the origin and process of China's move to internationalize its home currency? How different (or similar) is RMB internationalization from the currency internationalization of interwar Germany and postwar America? What is the international destiny of the RMB? By addressing these questions, this study challenges three prominent views of RMB internationalization: realist determinism, American exceptionalism, and liberal hype. Structural realists tend to claim the inevitability of RMB internationalization, as a rising power will seek to extend the influence of its currency abroad. The American exceptionalism view implies that as a beacon for the liberal international monetary order, postwar America adopted unique approaches to its currency internationalization, distinguishing itself from other great powers such as

*Injoo Sohn (isohn@hku.hk) is currently a CEAP visiting fellow at the Brookings Institution and an associate professor at the University of Hong Kong. He was a postdoctoral fellow in the PrincetonHarvard China and the World Program, commissioner of the Warwick Commission on International Financial Reform, and consultant of the Intergovernmental Group of 24 and the United Nations Conference on Trade and Development.

The Korean J ournal of International Studies Vol.13-1 (April 2015),181-206. http://dx.doi.org/10.14731/kjis.2015.04.13.1.181

(c) 2015 The Korean Association of International Studies 
interwar Germany and contemporary China. ${ }^{2}$ The liberal hype view presupposes that reform-minded liberals have been in the driver's seat of RMB internationalization, getting the Chinese economy to integrate into the West-centered liberal monetary order, leading to 'eventual assimilation.' These views are at best partially correct but cannot provide complete explanations about the process, nature, and prospect of RMB internationalization.

The focus of the article is two-fold: the feedback dynamics of RMB internationalization and a cross-country comparative overview. First, this article argues that a feedback model can be useful for our understanding of the process, timing and direction of RMB internationalization. The presence of a positive feedback loop is a significant contributing cause for Beijing's promotion of RMB internationalization. China's positive experiences with RMB regionalization in the first half of the 2000s contributed to increasing the legitimacy and influence of pro-RMB internationalization coalitions within China. The rise of the currency internationalization activists resulted in Beijing's ambitious experiment with RMB internationalization in the early 2010s. Beijing's experiment-based approach enabled Chinese policy makers to adopt both liberal and illiberal components of currency internationalization. As such, the findings of this study problematize assumptions of the views of the realist determinism and the liberal hype.

The article's comparative overview aims to explore the nature and prospect of RMB internationalization by identifying key similarities and differences among interwar Germany, postwar America, and contemporary China in their currency internationalization. Some common elements of the three cases debunk the myth of American exceptionalism. This comparison also reveals important structural factors that may contribute to a slow path to full RMB internationalization and the emergence of the hybrid model of China-centered monetary order in the East Asian region.

The article is organized as follows. The first section discusses the structural realist view of RMB internationalization and its limitations. The second section of the article addresses the competing logics of liberals and conservatives regarding RMB internationalization and their asymmetrical power relations within China. Thirdly, this study introduces a feedback model to explain the political process of RMB internationalization. The following section identifies several similarities

\footnotetext{
${ }^{1}$ Currency internationalization can be defined as the process by which a local currency becomes increasingly used outside of its national borders.

${ }^{2}$ While recognizing the different variants of traditional 'American exceptionalism' - that America differs qualitatively from the rest of the world _this study adopts the term exceptionalism for the purpose of highlighting that postwar America was not a unique exemplar of liberal virtue in currency internationalization.
} 
and differences among the currency internationalizations of interwar Germany, postwar America, and post-Mao China in order to illuminate the hybrid nature of RMB internationalization. This article ends by discussing key structural factors that may reflect and reinforce a slow path to full RMB internationalization in comparative perspective.

\section{IS RMB INTERNATIONALIZATION INEVITABLE?}

Realist approaches tend to emphasize the role of structural power or the balance of power in the origin of monetary diplomacy in East Asia (Grimes 2009; Kirshner 2007; Sohn 2007). Realists trace the sources of international monetary policy to: (1) power rivalry among China, Japan, and the United States, which often use their home currency as a convenient tool of statecraft; or (2) a state's defense mechanism against international financial crises or the aggressive behavior and destructive policies of the dominant player. With respect to currency internationalization, namely, an important element of broad monetary diplomacy, realists hold that a rising great power with growing international political ambitions will seek to enhance the influence of its currency abroad. From this perspective, great powers that have been in a position to extend the reach of their currencies have consistently attempted to do so throughout modern history. Powerful states such as Britain, France, Nazi Germany, Imperial Japan and the United States have routinely sought to encourage the international use of their currencies in order to achieve greater freedom of action and increased political influence (Kirshner 2014, 216). There is an historical pattern in which the international use of a currency has tended to correspond with the rise and fall of a state's economic power (Eichengreen 1994).

Such realist views have some explanatory power but are ultimately incomplete. The main problem with power-oriented realism is that the degree of material power cannot point to any particular policy direction. Realists have problems explaining why great powers like China choose to internationalize their currency. Currency internationalization is not the only way to achieve policy autonomy, increase political influence, or defend against global financial crises and the destructive behavior of great powers, and neither is its emergence inevitable. More recently, states have been more cautious about internationalizing their currencies. For example, West Germany and Japan were reluctant to promote the internationalization of their currencies after the collapse of the Bretton Woods monetary system in the early 1970 s due in part to their fear of losing control of domestic monetary policy. US efforts to promote dollarization in Latin America 
have continued to wax and wane over the past century despite their consistent asymmetrical power relations; furthermore, as an overwhelmingly powerful state, the United States had actively discouraged many countries in Central America and the Caribbean from "dollarizing" their domestic monetary systems during the 1940 s and 1950s (Helleiner 2002).

Another problem with the realist view is that they do not solve the puzzle of the timing of policy change. The use of the RMB as global payment currency has lagged far behind China's global economic power as the world's top official creditor, top trading state and second largest economy. 3 Realists might want to defend their hypotheses by indicating a possible 'time-lag' between realist considerations and actual policy behavior in the Chinese case. From this perspective, it might take a few years or a decade for Chinese policy elites to translate the power shift or balancing logic into actual policy changes. This objection is plausible but unconvincing since structural realists tend to leave unanswered the questions of whether, why, and how this time-lag might occur. The burden of proof lies with the realist skeptics. Unless they can provide a convincing explanation of the micro-level process of the time-lag, their objections remain hypothetical and thereby do not undermine my critique that the realist model provides incomplete explanations on the timing of RMB internationalization. As will be discussed later, a feedback model can be useful for understanding the micro-level dynamics of RMB internationalization.

\section{WEAK LIBERALS AND STRONG CONSERVATIVES}

Beijing's move to internationalize its currency was first prompted by the liberal logic of financial efficiency, innovation, opening, and liberalization. For liberals, the early stage of RMB internationalization, in the form of bilateral currency swaps, offshore RMB markets, and trade and investment settlements in RMB, would expose China to global practices and standards and lock China into further financial liberalization. Some reform-minded policy elites believed that RMB internationalization would also enhance the funding capacity of Chinese financial institutions, and thus the international competitiveness of the Chinese financial industry. With RMB expansion, Chinese financial institutions could make more international loans and investments, and this would raise the profile of Shanghai

\footnotetext{
${ }^{3}$ As of early 2014, the RMB, with a 1.39\% market share of global payments, remains well behind the US dollar, euro and pound sterling in particular, as well as the yen and Canadian and Australian dollars, as a global payment currency (Dean 2014).
} 
as an international financial center (Gao and Yu 2011). As Ulrich Volz $(2012,2)$ aptly notes, "Reformers within the Chinese government, with the People's Bank of China (PBOC) at the helm, are trying to use currency internationalization as a means to push forward with domestic financial and monetary reform." The link between financial liberalization and RMB internationalization was also recognized in an internally circulated Chinese government report. The report emphasized that the liberalization of financial markets could help ensure currency internationalization: "With the increase of a country's local currency held by foreign residents and officials, the country should be asked to open its financial market and provide non-residents who hold the local currency with a place worthy of stock and investment...the opening of financial market offers non-residents a huge 'capital pool', which would significantly support currency internationalization" (Financial Study Report 2012, 1).

The aforementioned logic of the liberal view has competed with conservative (or neo-mercantilist) logic in Chinese policy discourse. The neo-mercantilist logic stresses the implications of RMB internationalization for export competitiveness, industrialization, policy autonomy and political stability. The contemporary Chinese leadership has linked its international monetary policy making (including currency internationalization) with its commitment to rapid state-led industrialization and development. Such developmental-state frames were first articulated by Sun Yat-sen in the early 2oth century and experienced resurgences during the Bretton Woods negotiations in the 1940s and in Deng Xiaoping's reform strategy in the late 1970s (Helleiner and Momani 2014, 45-70). From a conservative perspective, wider international use of the RMB (through greater global demand for the currency) will likely drive the value of the RMB upward. This appreciation pressure may hurt exports as it reduces price competitiveness in global markets (it was for this reason that the German Bundesbank and the Bank of Japan did not actively support increasing the international roles of the deutschmark and the yen, respectively). For China, full-fledged RMB internationalization would eventually also put an end to the de facto dollar link, which could cause a significant appreciation against the US dollar and negatively impact Chinese manufacturing/export industries. Job losses in such sectors might generate domestic unrest, undermining the Chinese leadership's grip on power at home.

Conservatives also fear that RMB internationalization could considerably constrain the autonomy of its monetary policy. Large cross-border RMB movements could influence China's interest and exchange rates, as well as domestic prices, thus making it more difficult for the central bank to control domestic monetary policy. Furthermore, conservatives point to the hazards associated with capital 
accounts opening. As evidenced by the crises experienced in countries like South Korea and Mexico shortly after their financial openings, swift liberalization of capital accounts runs the risk of precipitating a financial crisis. It is particularly risky to implement a fast liberalization without having a sound financial regulatory regime. Following the Asian financial crisis in the late 1990s, Chinese leaders learned from post-crisis Indonesia that financial and economic crises could cause social unrest, political instability and even regime change. 4 Thus, a Chinese government report suggested that although full RMB convertibility is the ultimate goal of Chinese foreign exchange system reform, Beijing should proceed cautiously by implementing financial reform carefully while simultaneously increasing regulatory capacity in order to balance efficiency with security (International Finance Study 1998, 33-39).

Although Chinese liberals and conservatives seem to compete at the ideational level, there is significant political asymmetry. Liberals are politically much weaker than conservatives in China. First, the relatively weak influence on Chinese policy making of societal or private business groups who are supportive of financial liberalization should be noted. State-owned business elites are closely aligned with the Chinese Communist Party. Politically powerful state-owned enterprises (SOEs) and state-controlled banks tend to resist financial liberalization and openings because it would undermine their control over policy and finance that have been crucial for China's investment-driven, export-led development model. In China's political structure, private actors - including the Chinese public - are very weak and largely excluded from the policymaking process. 5

Within the Chinese government, more power rests with government agencies that ally with the SOEs. There also is a liberal-conservative division within the $\mathrm{CCP}$ and state agencies, with reform-minded liberals best represented within the People's Bank of China (PBOC), China's central bank. Conservatives are represented by the Ministry of Finance (MOF), the National Development and Reform Commission (NDRC), and the State Asset Supervision and Administration Commission (SASAC). As the PBOC has less political clout than other ministries, it has lost policy battles in this area. For example, the PBOC used to have control over foreign reserve and exchange rate policy but has been forced to share the

\footnotetext{
${ }^{4}$ For discussion of the impact of the Asian financial crisis on Chinese policy ideas, see Sohn (2008).

${ }^{5}$ The Chinese public also grew unhappy with the fact that a large portion of Chinese savings had been moved abroad, in the form of China's investment in U.S. Treasury bills, rather than invested domestically to raise Chinese living standards and upgrade Chinese domestic infrastructure. However, their voices could be easily dismissed in China's monetary policymaking process.
} 
decision-making authority with the MOF regarding key monetary policies (Jiang 2014, 163). This power asymmetry might raise the following questions: Why and how could Beijing continue to push forward with RMB internationalization by heading off politically strong conservatives who oppose extensive financial liberalization and prioritize economic security? A feedback model will be introduced to address this puzzle in the following section.

\section{FEEDBACK MODEL ${ }^{6}$}

This section discusses the feedback model to explain the policy process of RMB internationalization and Chinese monetary diplomacy. The feedback model presupposes non-linear interaction processes in which causation is mutual or circular rather than one-way (Jervis 1998). Feedback can be positive or self-amplifying when a change in one direction creates reinforcing pressures that lead to further change in the same direction. This positive feedback is similar to the concept of 'increasing returns' whereby actors reinforce the dominant logic, while the costs of switching to alternatives are heightened (Pierson 2000; Thelen 1999). Feedback can also be negative or dampening when the change produces forces that counteract the initial change and return the actors and institutions to something like their original position.

Feedback effects can occur on the organizational level. When the policy proposed by actors receives positive feedback, their political legitimacy and influence may increase within the government. Accordingly, their ideas are more likely to contribute to state policy. Conversely, when actors' policy ideas are seen as responsible for failed policies, they will lose their political legitimacy and influence. Thus, their ideas become less salient within the government (Jervis 1976).

\section{THE FEEDBACK DYNAMICS OF RMB INTERNATIONALIZATION}

The process of RMB internationalization features the aforementioned feedback dynamics. China's initiative to internationalize its currency goes back to the early 2000s, when some Chinese financial experts began to promote RMB 'regionalization'(renminbi yazhouhua 人鸟师亚洲化) as a stepping stone towards RMB 'internationalization' ( $\mathrm{Li}, \mathrm{Li}$, and Ding 2004, 2).7 The advocates of RMB

\footnotetext{
${ }^{6}$ This conceptual framework draws on the author's early work (Sohn 2012).
} 
internationalization, such as the $\mathrm{PBOC}$, framed policy proposals in ways that would be more acceptable to skeptics who prioritized national security (or power) over economic liberalization. ${ }^{8}$ One supporting view was that the early stage of RMB internationalization (regionalization) would enable China to enhance its influence over Southeast Asian countries (Zhao et al. 2003). From this perspective, a more regionally influential RMB could be viewed as an attractive means for a rising power such as China with aspirations to regional hegemony.

As the very first step toward the international use of the RMB, China's State Administration of Foreign Exchange issued rules and procedure for domestic institutions using the RMB as an invoicing currency in signing import and export contracts in 2003. In the early 2000s, the RMB was primarily used in trade near the border areas with countries such as Cambodia, Mongolia, Russia and Vietnam. Meanwhile, Hong Kong was chosen as a testing ground for evaluating the impact of possible RMB convertibility and capital accounts liberalization. Hong Kong's role as a laboratory for offshore RMB transactions began in 2004 with an arrangement that allowed the city to develop an offshore RMB deposit market.

An increasing number of Chinese policy analysts began to recognize the benefit of China's earlier efforts to internationalize the RMB. ${ }^{9}$ Even some conservatives held the view that the promotion of the RMB as a key regional currency could reduce China's dependence on the dollar and weaken the dollar's function in East Asia without significantly undermining Beijing's monetary policy autonomy. Beijing also recognized that a policy of low-key and incremental RMB internationalization would help to avoid any confrontation with Washington. This is in contrast with the case of Japan in which Tokyo's drive to internationalize the yen had been slowed down and undermined by opposition from Washington. Moreover, the initial experiment with the Hong Kong offshore market also turned out to be successful. Offshore RMB transactions via Hong Kong contributed to the wider use of the RMB while allowing the RMB to maintain relatively stable parity with dominant international reserve currencies such as the US dollar.

According to some Chinese interviewees, ${ }^{10}$ those who initially suggested the idea of RMB internationalization (notably the $\mathrm{PBOC}$ ) gained more attention from

\footnotetext{
${ }^{7}$ It should be also noted that earlier discussion about possible RMB internationalization emerged among Chinese financial experts back in the mid-1990s, but corresponding policy experimentation had been delayed due in part to the Asian financial crisis.

8 Author's interviews in Beijing and Hong Kong, May 2012.

9 Author's interviews in Beijing and Hong Kong, June 2013.

10 Author's interviews in Beijing and Hong Kong, May 2012.
} 
top leaders who became increasingly convinced that RMB internationalization would serve China's national interest. As the advocates of RMB internationalization were perceived to be responsible for policy success, they have been able to exert even more influence within Chinese policy circles and have been continuously encouraged to offer more detailed action plans to Chinese leaders since the mid-200os. Accordingly, the center of gravity of the Chinese governmental view shifted in favor of RMB internationalization in the mid-200os even before the 2008 global financial crisis. A key turning point appeared to come in 2006 with the publication of the report "The Timing, Path, and Strategies of RMB Internationalization" by the PBOC. "The time has come for promotion of the internationalization of RMB," the report argued. Internationalization "can enhance China's international status and competitiveness significantly [and] will increase its influence in the international economy (Cohen 2012, 1).

The 2008 global financial crisis has opened more policy space for the idea of RMB internationalization. As the US-originated global financial crisis, in particular, resulted in a weakened dollar and trade financing disruptions, Beijing moved decisively toward further RMB internationalization as means to reduce dependence on the dollar in terms of foreign reserve and trade settlement. In April 2009, China's State Council approved a pilot scheme for cross-border trade settlement in RMB. Shanghai, four cities in Guangdong Province, and Hong Kong were initially eligible to participate. In June 2010, program eligibility was expanded to include 20 of the 31 mainland Chinese provinces. The expansion of geographic coverage seemed to contribute to a notable increase in the volume of cross-border trade settled in RMB, which grew from less than RMB 4 billion at the end of 2009 to RMB 290 billion by the end of 2010.

In addition to the RMB trade settlement schemes, Beijing also made a series of bilateral currency swap agreements with other economies during the recent global financial crisis, which were designed to alleviate the trade contraction effect of the US dollar shortage and to help stabilize China's export sector. As of late 2013, China has signed bilateral currency swap agreements with 23 jurisdictions worth approximately RMB 2.5 trillion, including Argentina, Brazil, Russia, France, Hong Kong, Iceland, Indonesia, South Korea, Malaysia, Pakistan and Singapore. This monetary measure generated positive feedback dynamics within the Chinese government. In China's view, the usage of RMB in trade and bilateral swap arrangements has help China strengthen its relationships with targeted countries and improve its image as a "responsible great power." 11 This would contribute to

\footnotetext{
${ }^{11}$ Author’s interviews in Beijing and Hong Kong, June 2013.
} 
creating a more peaceful and favorable regional environment for China's economic development. The positive feedback dynamics continued to reinforce China's experiment with RMB internationalization in the early 2010 .

Accordingly, in June 2012, Hong Kong launched a cross-border RMB and Hong Kong dollar repurchase market. This new program aims to provide RMB to the rest of the world by allowing foreign financial institutions to tap offshore RMB via secured lending. Through this platform, financial institutions in Hong Kong were expected to lend RMB to help foreign institutions increase their offshore RMB liquidity pool outside of Hong Kong, which could in turn be used to support RMB trade settlements and RMB-related investment. At the same time, Beijing has gradually allowed foreign financial institutions more investment freedom and options in order to promote the internationalization of the RMB. For instance, in March 2013, Beijing permitted greater latitude for offshore RMB funds to invest in RMB-denominated stocks, bonds and other assets. In November 2014, China also launched the pan-China cross-border scheme allowing companies across China to participate in cross-border RMB two-way cash-pool sweeping.

The process of RMB internationalization to date confirms the view that this project is by no means a shock therapy-style or explosion-style course of reform (People's Daily 2012). In January 2011, Dai Xianglong, former governor of China's central bank, likewise noted that the internationalization of the RMB would take 15 to 20 years (China Times 2011). ${ }^{12}$ It is likely that RMB internationalization will continue to follow an experiment-based methodology; that is, first gaining experience in a small number of selected sites and then, based on local experience, spreading to larger areas. This policy experimentation has been a consistent element of post-Mao reforms in a variety of issue areas such as private business restructuring, state-owned enterprise reforms, financial reforms, and rural de-collectivization (Chung 2000; Naughton 1996; Zweig 2002). Policy experimentation is also an important element of the feedback dynamics occurring in Chinese foreign financial policy. The positive feedback on the earlier initiatives of RMB internationalization can explain why the Chinese top leaders (who are not necessarily reform-minded economists) could continue to push forward with RMB internationalization. The positive results of the limited scope of $\mathrm{RMB}$ internationalization have expanded the Chinese constituency of pro-RMB internationalization supporters by addressing the conservatives' concerns

12 Dai went on to articulate China's likely path for currency internationalization by pointing out the following three-stage process: 1) use of the RMB as a trade settlement currency; 2) permission for investors to enter and withdraw RMB from China; and 3) expansion of the RMB to an international reserve currency. 
including financial stability, capital control, slow economic adjustments and national security. ${ }^{13}$ Such a political compromise through the experiment-based feedback process helped to lead even those illiberal conservatives who remain skeptical of the liberal view to support the RMB internationalization that was initiated by politically weak liberals within the Chinese government.

\section{KEY POINTS OF SIMILARITY AND DIFFERENCE: COMPARING INTERWAR GERMANY, POSTWAR AMERICA, AND POST-MAO CHINA}

One can identify several points of similarity and difference among the currency internationalizations by Germany of the 1930s, the United States of the 1960s, and China today. The illiberal logic of Chinese conservatives also can be found to some extent in the cases of both interwar Germany and postwar America. ${ }^{14}$ In other words, the American case represents a discrepancy between its liberal vision and actual behavior during the early postwar period. This section discusses four notable features - the use of capital controls, bilateral settlement, a strategy to delay, and the ease of convertibility in comparative perspective. This minicomparison illuminates the hybrid nature of Chinese RMB internationalization. Some caveats are in order. This section does not intend to make a systematic test of relevant theories or conduct an in-depth case study of specific financial policies. For reasons of space, this comparative overview focuses on some salient indicators of the illiberal attributes of currency internationalization. Despite the potential danger of selection bias, hopefully this approach may generate useful insights and hypotheses that can be tested by future research in a more rigorous manner.

\footnotetext{
${ }^{13}$ The conservatives' concerns will be further elaborated in the next section.

${ }^{14}$ It is worth noting that America launched its first 'dollar internationalization' policy in 1914, challenging the hegemonic status of the pound sterling and London in the international monetary system. However, this study focuses on postwar America for two reasons. First, the earlier attempt by the United States to internationalize its currency coincided with the First World War, which interrupted the provision of global financial services by London. The perceived uniqueness of the wartime dollar internationalization makes it more difficult to compare to RMB internationalization, an example of peacetime currency internationalization. Second, since postwar America is commonly portrayed as a liberal great power promoting an open, liberal international economic order, it can be juxtaposed with illiberal great powers to examine the validity of the liberal vision of American exceptionalism regarding currency internationalization.
} 


\section{THE USE OF CAPITAL CONTROLS ${ }^{15}$}

A particularly interesting similarity among Germany of 1930s, the United States of 1960s, and today's China is that all three appreciated and employed capital controls to varying degrees. Many European countries pursued capital controls when confronted with banking crises, falling foreign exchange reserves, and capital flight in the early 1930s. Some countries, including Germany, were concerned that floating exchange rates, without capital controls, would trigger hyperinflations similar to those seen in Europe in the early 1920s. Germany imposed extensive capital controls and established a complex system of bilateral trade clearing agreements in the 1930s (Neal 1979). German capital controls were intended to prevent capital outflows and to keep the official foreign exchange rates for the Reichsmark at the old parity. When Germany and several central European countries imposed exchange controls, other trading partners felt pressure to follow suit (Ellis 1941).

Capital controls were also common in the United States and Western Europe during the early postwar period. Despite the rise of a 'Euro market,' or offshore dollar market, and subsequent increases in financial openness, the United States and Western European governments remained committed to the 'restrictive' Bretton Woods financial order. In the early postwar period, US leaders were skeptical about the benefits of a liberal financial order. Even the American Bankers Association admitted that the free capital movement was speculative, unproductive, and tax evasive (Helleiner 1994, 87). Most European countries maintained capital controls well into 1980s, and throughout the 1960s and 70s, the United States did not pressure other countries to remove their capital controls. Washington opted for capital controls by imposing a special tax on interest earnings on foreign deposits (the Interest Equalization Tax) from 1963-1974 and a voluntary control program when it confronted a capital outflow. As a result, for much of the 1960 s, the London-based offshore dollar market remained strictly separated from the tightly regulated national financial systems of the United States and Western European countries - a two-track approach to financial regulation. By providing offshore dollar market operators with an extra degree of freedom and avoiding comprehensive exchange controls, however, Washington's use of capital controls was more moderate and limited in comparison to interwar Germany's approach.

\footnotetext{
15 The norm of capital controls, which was widely accepted during the early postwar period but delegitimized in the 1980 s and 1990s, has regained legitimacy among global institutions. In 2010, the International Monetary Fund (IMF) revised its position against capital controls, recognizing that sudden capital surges can put some countries at risk; therefore, capital controls can be utilized to avoid financial crises.
} 
The Chinese government similarly drew a sharp line between onshore and offshore RMB markets in terms of financial regulation. Chinese authorities continue to impose tight restrictions on the international use of the RMB in domestic financial markets while gradually allowing more freedom for market players in the offshore RMB market. ${ }^{16}$ Beijing was aware that the offshore dollar market provided a base for the speculative activities of market operators in the 1960s, and that European states such as France, Italy and Scandinavian countries resorted to capital controls to preserve their policy autonomy as financial openness threatened to constrain interest rate policy and credit rationing arrangements that had served as key tools in their economic planning and industrial strategies. Such understanding has reinforced Beijing's preference for maintaining capital controls. Nevertheless, it is also true that Beijing has taken a gradual and cautious approach to the relaxation of capital controls over the past decades. A series of measures to reform the structure and degree of capital controls has been implemented in sequence - "liberalizing long-term flows before short-term flows, liberalizing direct flows before indirect flows, and protecting the country's weak domestic sectors from external competition and unwanted shocks" (Gao and $\mathrm{Yu}$ 2011, 119). ${ }^{17}$ Although China is unlikely to dismantle all the instruments of capital controls in the foreseeable future, it is noticeably different from Germany of the 1930 in terms of the extent of capital controls.

\section{BILATERAL SETTLEMENTS}

Interwar Germany created a bilateral trade clearing system to offset the distortionary price and trade effects of capital controls. The bilateral clearing agreements, designed by Hjalmar Schacht in 1934, linked with a system of managed ASKI accounts (Foreigner's Special Accounts for Inland Payments) and fixed exchange rates in order to avoid the need for gold and foreign assets. At its height, they covered about half of all German foreign trade involving 25 countries (Neal 1979). The new instrument of the bilateral clearing system was the ASKI mark, a blocked or non-convertible currency. The ASKI mark is the term used to designate the mark that would be received in the first instance by foreign exporters of

\footnotetext{
${ }^{16}$ One slight difference in the use of capital controls was that, while the United States of the 1960 s and Germany of the 1930s utilized capital controls to prevent capital outflow from exacerbating their balance-of-payments deficits, China to date has shown relatively more concern about preventing short-term capital inflow from disrupting domestic anti-inflationary policies and exacerbating large balance-of-payments surpluses.

${ }^{17}$ According to IMF categories of capital controls, by the end of 2007, for example, half of the types of capital account transactions were subject to controls, and half of the types of cross-border capital transactions were open to both non-residents and residents.
} 
goods to Germany. They could sell their ASKI marks to the importer of goods from Germany who then used them to pay the German price. This mechanism helped Germany control and manipulate economic transactions with its trade partners in eastern/southern Europe and Latin America, which were holding large amounts of ASKI marks or unused mark credits, thereby supporting the value of their marks. Germany of the 1930s used the mark system to "alter and harmonize the preferences of its neighbors...facilitate its policy of regional autarchy, insulating its national economy, separating the region from the world economy, and mobilizing... the materials needed in the preparation for war" (Kirshner 1995, 136). In other words, the bilateral clearing system was interwar Germany's financial statecraft to achieve its foreign policy goals. This illiberal financial statecraft was embedded in Germany's national strategy in the 1930s. This is in stark contrast to postwar America's monetary diplomacy. Although Washington sometimes adopted illiberal tools and instruments, its overall goal (or vision) was to develop an open, multilateral, nondiscriminatory system of payments based on the dollar. Even when Washington made bilateral swap arrangements with its major economic partners in the early 1960s, such bilateral mechanisms were primarily designed for offering dollars to countries facing a liquidity crisis, not for the purpose of regional autarchy.

Like interwar Germany, Beijing has promoted the use of RMB in trade through bilateral clearing agreements with its trade partners. The bilateral agreements enable traders to settle trade in RMB either by acquiring RMB to pay for Chinese imports or accepting RMB as payment and then exchanging it for their local currency. The Chinese authorities put a cap on the net inflow and outflow in trade settlements through state-controlled commercial banks. In other words, these banks should have both export and import business in similar amounts (Jiang 2014, 182). These arrangements aim to allow China and its trade partners to offer RMB trade financing for their imports and exports in a controlled manner while avoiding the exchange rate volatility of the US dollar. These bilateral trade settlements might also have the potential of deepening monetary interdependence between China and its key trade partners by inducing them to shift to the RMB as a key medium of exchange for trade settlement.

However, there are also significant differences between interwar Germany and post-Mao China. RMB internationalization features more liberal elements of currency internationalization in the domain of investment and financial markets. ${ }^{18}$

${ }^{18}$ Some observers note that China has embarked upon a "two-track" strategy to achieve RMB internationalization (Subacchi 2010). The first track focuses on promoting the use of the RMB in onshore and offshore financial markets while the second track aims to increase the currency's use in 
As discussed earlier, Beijing has taken some modest measures to encourage the use of RMB in outward and inward direct investment in addition to trade settlement. Moreover, China also made bilateral convertibility agreements with some countries including Japan and Australia, allowing direct currency trading on foreign exchange markets even though their impact on RMB is very limited due to the limited degree of openness of the Chinese financial market. Unlike interwar Germany, Beijing also attempted to develop offshore RMB centers (e.g. Hong Kong, Singapore, Taipei, London, and Frankfurt) to internationalize the RMB and facilitate opening of the onshore RMB market. A milestone of the offshore market experiment was the issuance of so-called "Dim Sum" bonds: bonds denominated in RMB and issued in Hong Kong. These initiatives, albeit limited in scope and pace, echo the liberal view of the international use of the Chinese currency.

\section{A STRATEGY TO DELAY}

Another notable similarity is that both the United States and China appear to have promoted international use of their currencies as part of their illiberal strategy to delay their own domestic economic adjustments. Confronting growing external deficits in the 1960s, Washington sought to avoid and postpone adjustment measures by urging foreign governments and private investors to finance the deficits. The appeal of dollar holdings to foreigners was central to this delay strategy, and the emergence of the Eurodollar (or offshore dollar) market was useful in that regard. Due to the liquidity and the absence of interest rate regulation in the Eurodollar market, for instance, dollar holdings could receive market rates of interest that were higher than those in the United States. The attractiveness of the newly emerging Eurodollar market thus helped the United States persuade foreign institutions to finance its external deficits through dollar holdings. This enabled Washington to preserve its policy autonomy and delay painful domestic adjustments (Helleiner 1994, 90-91; Strange 1971). In other words, the US current account deficit was significantly reduced not by adjustments to the US economy but by the transfer of the adjustment burden to foreigners through dollar purchases by foreign governments or revaluation of foreign currency - what is called the "dollar weapon."

Chinese conservatives also seem to endorse the development of offshore RMB markets as a means to slow down or delay domestic adjustments and economic

international trade and direct investment settlement. From this perspective, interwar Germany's currency internationalization concerns only the trade dimension of the second track, lacking financial markets and investment. 
reform. China's rapidly growing trade surplus and massive buildup of foreign exchange reserves have led to excessive money growth and RMB appreciation pressures. RMB internationalization can be one policy option to moderate the inflow of the dollar and thereby lessen the inflationary overheating of China's economy without making significant and rapid adjustments to its export-led growth model. Dollar inflows and accumulation driven by trade surpluses could generate an expansion in the Chinese domestic money supply (or inflation) as massive dollar holdings prove difficult to sterilize. Beijing appears to use RMB internationalization (as well as a sovereign wealth fund) to mitigate such side effects and protect policy autonomy. For instance, the expanded pilot scheme for cross-border trade settlement in RMB is intended to reduce US dollar inflows into China, as these inflows were perceived to be responsible for RMB appreciation pressures and the bloating of US dollar foreign exchange reserves.

Despite Beijing's rhetoric about the need to transform its economic growth into a domestic consumption-led model, the core elements of the existing export-led development model must be sustained, at least in the short run, to ensure high growth rates, employment, and political stability. In the face of liberal concerns about the unsustainability of the Chinese development model, such a large-scale economic transition remains, at best, a distant goal. It cannot be achieved overnight. South Korea, for example, has yet to abandon an export-led development strategy despite a series of liberal economic reforms. ${ }^{19}$ Beijing has a clear interest in continuing to control and manipulate RMB exchange rates to keep its own goods cheap and sustain its neo-mercantilist policies. ${ }^{20}$ Full-fledged and rapid financial liberalization is not the paramount goal of the current set of top Chinese leaders, who are by no means liberal economists. Like the United States of the 1960 s, currency internationalization is perceived by the Chinese conservatives (or neo-mercantilist) as a useful tool to delay painful economic restructuring programs. Such realpolitik tendencies appeared in the monetary diplomacy of both postwar America and post-Mao China.

\footnotetext{
${ }^{19}$ Similarly, the economic growth of postwar Germany and Japan has been export-led and manufacturing-driven. The core feature of the German and Japanese model remains largely intact.

${ }^{20}$ China has been constrained by the rules and norms of a highly institutionalized global economy. But China has never fully internalized the Western ideal of liberal and open globalization. Although it might criticize the protectionism of other advanced countries, China practices its own form of protectionism, keeping its own goods cheap by ensuring that the RMB remains weak. Although it may advocate competition at home, its own economy remains very much under the direction and control of the state. However, it is also important to note that mercantilist behavior is not a unique component of China's rise. Other rising powers of the past, including the United States of $19^{\text {th }}$ and early $2 \mathrm{O}^{\text {th }}$ century, also practiced their own form of the same. For the case of the United States see Buzan and Cox $(2013,14)$.
} 


\section{THE EASE OF CONVERTIBILITY}

The most obvious difference between China and the United States, as many observers like to point out, is convertibility. A currency can be seen as 'fully convertible' when any holder is free to convert it at a market rate into one of the major foreign currencies. The convertibility of the dollar and the pound sterling was achieved before the Eurodollar market was created in London. In contrast, both the Reichsmark of interwar Germany and the RMB of contemporary China are not freely convertible. The restricted RMB (as opposed to multilaterally-convertible dollar) made it possible for Beijing to take a cautionary and conservative approach to RMB internationalization. Moreover, domestic and offshore RMB are not interchangeable in the same way that Eurodollars and dollars have been; getting into the offshore RMB pool involves moving in or out through a bottleneck controlled by clearing agreements between China's central bank (or the PBOC) and one of China's major banks (e.g. the Bank of China) on one end, and one of China's major banks and other local clearing banks in offshore RMB centers (e.g. Hong Kong) on the other.

It should be noted, however, that offshore RMB can become a globally available and transferrable currency, at least in theory, even as it remains non-convertible. This is because offshore RMB is not limited to the Hong Kong market. As of 2014, foreign institutions and companies outside Hong Kong are, or will be, allowed to open an offshore RMB account with their respective offshore RMB clearing bank in London, Frankfurt, Singapore, Taipei, Seoul, Paris and Luxembourg, in the same way that a US dollar account can be opened outside the United States. These offshore RMB clearing banks can maintain an RMB account with one of China's main banks participating in the clearing arrangement with the PBOC. This byzantine series of accounts allows offshore RMB to become globally transferable and accessible via Hong Kong and other offshore RMB centers. ${ }^{21}$ This complex and hybrid model suggests that while RMB falls far behind a multilaterally convertible dollar in terms of global availability, it is nevertheless more accessible and transferrable than interwar Germany's currency due to offshore RMB markets.

\footnotetext{
${ }^{21}$ It is feasible that foreign banks outside Hong Kong would develop their own bilateral clearing agreements directly with the PBOC. The PBOC announced a plan to set up the China International Payment System (CIPS), a cross-border payment system that facilitates greater use of the RMB and partly replaces China's existing clearing system.
} 


\section{CAN RMB BECOME A NEW LIBERAL HEGEMONIC CURRENCY IN THE INTERNATIONAL MONETARY SYSTEM?}

The preceding section discussed both the liberal and illiberal components of RMB internationalization. This begs another important question about the future of the RMB: will RMB internationalization go down the same path as postwar America, integrating with the existing liberal monetary order? Does the RMB have the potential to achieve the status of a hegemon, replacing the dollar in the global currency hierarchy? Comparing today's China with the United States of the 1960 also sheds light on several distinctive structures that might condition China's choice about RMB internationalization. They include a lack of hegemonic power, weak non-state actors, normative fragmentation, different comparative advantage, and the absence of security alliances. These ideational and material structures are likely to hinder the RMB from becoming a liberal or hegemonic currency in the near future.

\section{THE STATUS OF HEGEMON}

The US dollar reached prominence in the 1950s and 1960s even though foreign governments (e.g. France) were discontented with the perceived abuse of American seigniorage privileges and the inflationary effects of dollar holdings on their domestic money supply. In the current international financial system, however, China falls short of achieving the status of hegemon, a status that was enjoyed by the United States even before the emergence of full-fledged offshore dollar markets. The albeit weakening dominance of the US dollar as a key international currency today naturally limits the attractiveness of RMB holdings to foreigners. However, this does not mean that China cannot develop and use a kind of market-based power in global finance in the long run. The relative size of the Chinese economy and growing foreign reserves have enabled Beijing to employ market pressure to change the range of choices open to its trade partners generally, and smaller neighboring countries in particular. As a regional hegemon, China is capable of pressuring its regional trading partners to use RMB to finance their trade with China. Nevertheless, it seems that the dollar-centered global currency system will continue to constrain the scope and pace of the international use of the RMB in the near future.

\section{THE RELATIVE STRENGTH OF NON-STATE ACTOR}

Another notable difference is the relative strength of non-state actors. Although both American and Chinese governments played a significant role in the early development of the internationalization of their respective currencies, American 
non-state actors were more influential and visible than their Chinese counterparts throughout the process. As Eric Helleiner (1994) aptly notes, America's support for the Eurodollar market was related to the response of the private sector to the US capital control program. While American bankers had failed to prevent the capital control program by the early 1970s, they managed instead to use the offshore dollar market to evade US domestic financial regulations and finance their overseas operations, leading to the reemergence of global finance.

By contrast, the Chinese financial industry has been overwhelmingly dominated by a few of state-controlled financial institutions as discussed earlier. Chinese private financial institutions and China-based multinational corporations (MNCs) remain both politically and economically much weaker than those American companies that had gained a direct stake in the emerging international liberal monetary order in the 1960s and 1970s. By the early 1970s, MNCs and bankers were lobbying the US government to remove capital controls and facilitate financial liberalization. Powerful Chinese state-owned enterprises (SOEs), however, stand to gain from the current Chinese illiberal financial system and have a huge stake in state-led development. Chinese SOEs that have heavily relied on grants and hidden subsidies from the Chinese government might have less enthusiasm for financial liberalization even though the Chinese leadership has expressed its political willingness to reform the Chinese economy. In other words, China's path to its currency internationalization is more likely to reflect the nature of a state-controlled capitalism that is characterized by increased, yet limited, use of the market mechanism combined with state ownership and control of the most strategic sectors of the economy.

\section{NORMATIVE FRAGMENTATION}

Offshore dollar and RMB markets also were developed within a different normative structure at the international level. With rare exceptions, capital controls were very much the norm in the 1960s when the Eurodollar market emerged whether in developing or developed countries - as this was the heyday of the Keynesian view of interventionist economic management. Over the 1970s, prevailing norms that supported capital controls eroded and were replaced in subsequent decades by the market-oriented ideas of financial liberalization (the "Washington consensus"). In the 21st century, however, such hegemonic neoliberal ideas appear to be on the decline, and normative fragmentation (or the absence of a new global consensus) on global financial governance seems to gaining traction (Sohn 2012).

Normative fragmentation driven by international financial crises, especially the recent global financial crisis, has significantly undermined the 'soft power' of the 
United States and other G-7 countries. It has also reinforced Chinese skepticism about the Washington-knows-all (or universal) approach and heightened Chinese appreciation of their own development model wherein China puts domestic economic and social goals ahead of an open global economy in general, and currency internationalization in particular. Beijing takes the view that a national economy needs active management to ensure full employment and proper growth. This requires Chinese policymakers to have sufficient autonomy, or distance from volatile international financial markets, to conduct monetary and fiscal policy while taking a very cautious approach to financial liberalization and opening. ${ }^{22}$ This changing normative structure is more likely to discourage or slow down China's one-way assimilation into an American-centered liberal monetary order.

\section{DISTINCTIVE COMPARATIVE ADVANTAGE}

One can also note that the United States of the 1960s possessed a comparative advantage in finance, which China lacks today. In the 1960s, the United States and Britain were already major financial centers and in an advantaged position to gain from a more liberal and open international financial system. It was reasonable, then, for them to employ their own comparative edge to pursue prosperity, and the abolishment of capital controls would further increase demand for the services of Wall Street and the City of London.

However, China's financial market was still underdeveloped during the early stages of RMB internationalization. Despite China's interest in, and passion for, establishing a hub for global finance, Shanghai remains less likely to catch up with US financial markets in terms of their depth, size, and liquidity in the foreseeable future. China's comparative advantage still lies in labor mobilization within the traditional manufacturing sector. This factor reinforces Beijing's reluctance to champion financial liberalization and to put RMB internationalization ahead of other national development programs and strategies.

\section{SECURITY ALLIANCE SYSTEM}

The presence of formal alliances in the Eurodollar market and absence of the same in offshore the RMB market is another distinguishing feature. The creation of the Eurodollar market was supported not only by the United States but also by

\footnotetext{
${ }^{22}$ This is also reinforced by a growing anti-globalization sentiment within China. Chinese "new leftists' (xin zuopai) claimed that China's reform and opening policy has undermined its socialist integrity, corrupted its culture with negative foreign influences, and compromised its sovereignty and autonomy in world affairs. The recent global financial crisis further emboldened this line of thinking.
} 
key Western European allies during the early postwar years. The Cold War period gave US allies more political incentives to maintain economic and financial ties with the United States through the offshore dollar market. With political confidence and trust, London banks started to lend out Eurodollars to other corporate customers in Western Europe in the 1970s.

However, a rising China to date has eschewed pursuing and developing any strong formal military alliance system. Rather, the recent assertive and bellicose turn in China's international behavior in the East and South China Seas appears to have strengthened the perception of a 'China threat' across the region. For China's neighbors, there are political risks associated with deepening economic and financial integration with a more aggressive China, as Beijing may threaten to exploit its increased economic leverage. As a leading Hong Kong-based think tank has aptly noted (Chen and Cheung 2011):

Political considerations, especially in East Asia, could play a non-negligible role in choosing an international currency. The legacies of war, occupation, and communism have induced the antagonism towards regional hegemony... for its neighboring countries these [Chinese] reassurances may not be completely convincing, especially when China retains the communist political structure and expands its military capacity. All these considerations would require China to make some extra efforts to promote the acceptance of the RMB in Asia and in the global market.

The absence of formal alliance and the security concerns of China's neighbors seems to constrain the scope of China's political leverage to internationalize its currency. This is an additional structural obstacle facing the rise of vibrant offshore RMB markets and full-fledged RMB internationalization.

\section{CONCLUSION}

The process of RMB internationalization reflects Beijing's efforts to achieve the dual aims of reform-minded liberals and statist conservatives in an experimental and incremental manner. While Chinese liberals call for financial innovation and development through RMB internationalization, and the broader financial liberalization that accompanies it, the neo-mercantilist (or conservative) logic strongly influences the scope and pace of RMB internationalization. ${ }^{23}$

\footnotetext{
${ }^{23}$ The current Chinese leadership's efforts to centralize decision-making processes by strengthening the role of party organizations may further weaken the influence of reform-minded technocrats
} 
A closer look at the dynamic process of RMB internationalization may lead us to doubt the deterministic view of currency internationalization - the inevitable internationalization of the RMB. China's drive to internationalize its currency is gradually evolving. Although Chinese leaders have core strategic goals in mind, they have been groping their way forward with experiment-based monetary diplomacy. As mentioned above, RMB internationalization began to pick up momentum through positive feedback effects in the mid-20oos, leading to further expansion in the aftermath of the global financial crisis. However, the feedback model does not rule out the possibility that China's positive feedback can be ultimately replaced by negative feedback. It is conceivable that illiberal conservatives' support and tolerance will decrease as negative feedback occurs in the future. For instance, if RMB internationalization generates volatile capital inflows and outflows that make domestic monetary policy difficult, it may increase pressure to slow down or halt further RMB internationalization. One can also imagine that positive and negative feedback could operate simultaneously. China's experiment with RMB internationalization can set off positive feedback in one issue area (e.g. trade settlement) and negative feedback in another (offshore RMB markets). Thus the future of RMB internationalization is unwritten, and so wise policy matters.

This article has also examined the currency internationalization by Germany of the 1930s, the United States of the 1960s, and today's China in comparative perspective. This comparison can illuminate the hybrid nature of RMB internationalization, distinguishing the Chinese case from relatively more liberal (postwar America) and illiberal (interwar Germany) examples. Meanwhile, some similarities among the three cases may debunk the myth of 'American exceptionalism.' The post-war United States utilized illiberal, as well as liberal, logic and policies in the early stage of offshore dollar market development. Comparing post-war America with today's China also gives some insights into the prospect of an international RMB. The comparison can help us identify several prominent factors that may constrain RMB internationalization in particular, and China's financial liberalization in general. They include a lack of hegemonic power, weak non-state actors, normative fragmentation, different comparative advantage, and the absence of security alliances. These structural variables may conspire to undermine the greater international use of the RMB, even though internationalization is taking place in the context of a more market-based international mon-

within Chinese ministries. A number of new leading small groups and commissions created after the Third Plenum (November 2013) took a significant portion of policy responsibilities away from the state bureaucracy. 
etary order than that of the 1960s. Despite the strong momentum displayed over the past few years, the scale of the use of the RMB in the global market is very small when compared to the size of the Chinese economy (Dean 2014). The hybrid model of RMB internationalization and its limited use in the global market may not support the liberal hype that the RMB would become a globally convertible and dominant currency, ultimately assimilating into the existing liberal international monetary order. ${ }^{24}$ In effect, Chinese conservatives have tried to "promote internationalization on the cheap - to make as few concessions as possible in terms of either political or financial reform" (Cohen 2012, 9).

At this point, it is reasonable to conjecture that China is more likely to pursue a slow path to enhance the RMB's acceptance overseas, while seeking policy autonomy, economic security and political stability during the period of its rise. The RMB is unlikely to challenge, not to mention replace, the US dollar in the near future despite growing skepticism about the dollar's global role. One possibility is that RMB would encroach on the influence of the dollar and become one of the dominant currencies in East Asia unless the Chinese economy hits a major bump or a serious political crisis happens, a possibility not to be completely dismissed. Such a trend may contribute to the emergence of "an increasingly leaderless mix of currency relationships" in a post-global crisis world (Cohen 2009, 143). ${ }^{25}$

\section{REFERENCES}

Buzan, Barry and Michael Cox. 2013. "China and the US: Comparable Cases of Peaceful Rise.” Chinese Journal of International Politics 6 (2), 109-132.

Cohen, Benjamin J. 2009. “Toward a Leaderless Currency System.” In Eric Helleiner and Jonathan Kirshner eds., The Future of the Dollar. Ithaca NY: Cornell University Press, 142-163.

Cohen, Benjamin J. 2012. “The Yuan Tomorrow? Evaluating China's Currency Internationalization Strategy." Working paper. Accessed at

${ }^{24}$ President Xi Jinping's nativist-exceptionalist approach would also discourage China from further assimilating into the America-led liberal monetary order. President Xi's call for the Chinese Dream, and self-confidence about China's unique path, suggests that the core elements of the Western liberal order are unsuited to the Chinese context.

${ }^{25}$ In addition to the aforementioned 'China factor,' a prominent economic rationale for a leaderless currency system is that "the increasing returns to scale and network externalities that creates a tendency for importers, exporters, and international investors to gravitate toward one currency as a common unit of accounting and means of payment are less pronounced in a high-tech world where everyone has access to information on exchange rates in real time and currency conversion costs are low." See Eichengreen and Kawai $(2014,16)$. 
http://polsci.ucsb.edu/faculty/cohen/working/pdfs/NPE.pdf (November 10, 2013).

Chen, Xiaoli and Yin-Wong Cheung. 2011. "Renminbi Going Global." China \& World Economy 19(2), 1-18.

China Times. 2011. "China: The Internationalization of Yuan Will Take 15 to 20

Years." (June 27). Accessed at http://www.thechinatimes.com/online/ 2011/06/221.html (February 2, 2012).

Chung, Jae-Ho. 200o. Central Control and Local Discretion in China: Leadership and Implementation during Post-Mao Decollectivization. Oxford: Oxford University Press.

Dean, Carol. 2014. "Battle for European RMB trading hub supremacy intensifies." Euromoney (April 2). Accessed at http://www.euromoney.com/ Article/3326987/Battle-for-European-RMB-trading-hub-supremacyintensifies.html?copyrig htInfo=true (January 15, 2015).

Eichengreen, Barry. 1994. International Monetary Arrangements for the 21st Century. Washington, DC: The Brookings Institution.

Eichengreen, Barry and Masahiro Kawai. 2014. "Issues for Renminbi Internationalization: An Overview.” ADBI Working Paper 454, Tokyo: Asian Development Bank Institute. Accessed at http://www.adbi.org/ files/2014.01.20.wp454.issues.renminbi.internationalization.overview.p df (January 18, 2015).

Ellis, Howard S. 1941. Exchange Control in Central Europe. Cambridge: Harvard University Press.

Financial Study Report [Jinrong yanjiu baogao 金融研究報告]. 2012. “China’s Reference on Currency Internationalization Process of Euro, USD and Yen." 18.

Gao, Haihong and Yongding Yu. 2011. "Internationalization of the Renminbi.” In BIS and Bank of Korea eds., Currency Internationalization: Lessons from the Global Financial Crisis and Prospects for the Future in Asia and the Pacific. BIS Paper 61, 105-124.

Grimes, William W. 2009. Currency and Contest in East Asia: The Great Power Politics of Financial Regionalism. Ithaca, NY: Cornell University Press.

Helleiner, Eric. 1994. States and the Reemergence of Global Finance. Ithaca, NY: Cornell University Press. . 2002, "Dollarization Diplomacy: US Policy Toward Latin America Coming Full Circle?” Review of International Political Economy 10(3), 406-429.

Helleiner, Eric and Bessma Momani. 2014. "The Hidden History of China and the IMF." In Eric Helleiner and Jonathan Kirshner eds., The Great Wall of 
Money. Ithaca, NY: Cornell University Press, 45-70.

International Finance Study[Guoji jinrong yanjiu 国际金融研究]. 1998. “A Study on Financial Security Problems during Our Country's Opening [浇国对外 开放中的金融安全问题形究]” 5 .

Jervis, Robert. 1976. Perception and Misperception in International Politics. Princeton, NJ: Princeton University Press.

. 1998. System Effects: Complexity in Political \& Social Life. Princeton, NJ: Princeton University Press.

Jiang Yang. 2014. "The Limits of China's Monetary Diplomacy." In Eric Helleiner and Jonathan Kirshner eds., the Great Wall of Money. Cornell University Press, 156-183.

Kirshner, Jonathan. 1995. Currency and Coercion. Princeton, NJ: Princeton University Press.

. 2007. "Money, Capital and Cooperation in the Asia-Pacific Region." In G. John Ikenberry and Takeshi Inoguchi eds., The Uses of Institutions: The U.S., Japan, and Governance in East Asia. London: Palgrave Macmillan, 187-216.

. 2014. "Regional Hegemony and an Emerging RMB Zone." In Eric Helleiner and Jonathan Kirshner eds., The Great Wall of Money. Ithaca, NY: Cornell University Press, 213-240.

Li, Xiao, Junjiu Li, and Yiping Ding. 2004. "Discussion on RMB Regionalization [Lun renminbi de yazhouhua 论人民和的亚洲化].” World Economy [Shejie jingii・讨留经济], no 4.

Naughton, Barry. 1996. Growing out of the Plan: Chinese Economic Reform, 1978-1993. Cambridge: Cambridge University Press.

Neal, Larry. 1979. "The Economics and Finance of Bilateral Clearing Agreements: Germany, 1934-8." Economic History Review 32(3), 391-404.

People's Daily. 2012. "Yuan internationalization is not an "explosion-style reform" (June 11). Accessed at http://english.peopledaily.com.cn/90778/ 7842521.html (November 11, 2013).

Pierson, Paul. 2000. "Increasing returns, path dependence, and the study of politics." American Political Science Review 94(2), 251-267.

Sohn, Injoo. 2007. "East Asia's Counterweight Strategy: Asian Financial Cooperation and Evolving International Monetary Order." G-24 Discussion Paper 44.

. 2008. "Learning to Cooperate: China's Multilateral Approach to Asian Financial Cooperation.” The China Quarterly 194, 309-326.

. 2012. "After Renaissance: China's Multilateral Offensive in the Developing World." European Journal of International Relations. 
2012. "Toward Normative Fragmentation: An East Asian Financial Architecture in the Post-Global Crisis World." Review of International Political Economy 19(4), 586-608.

Subacchi, Paola. 2010. “One Currency, Two Systems': China's Renminbi Strategy." Chatham House Briefing Paper.

Strange, Susan. 1971. Sterling and British Policy. London: Oxford University Press.

Thelen Kathleen. 1999. "Historical institutionalism in comparative politics." Annual Review of Political Science 2, 369-404.

Volz, Ulrich. 2012. "Prospects of the Renminbi to Become a Global Currency." Paper presented for a workshop on financial statecraft at the University of Southern California (July 28).

Zhao, X. and et al. 2003. “China in Transition [Zhuanxing Zhongguo 转型㠹国].”

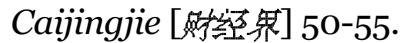

Zweig, David. 2002. Internationalizing China: Domestic Interests and Global Linkages. Ithaca, London: Cornell University Press.

[Received December 5, 2014; Revised March 2, 2015; Accepted March 13, 2015] 